\title{
Radiotherapy for inoperable Merkel cell carcinoma: a systematic review and pooled analysis
}

\author{
Parth Patel ${ }^{1}$, Chirag Modi ${ }^{2}$, Beth McLellan ${ }^{1}$, Nitin Ohri ${ }^{2}$
}

\begin{abstract}
1 Department of Medicine, Division of Dermatology, Montefiore Medical Center, Albert Einstein College of Medicine, Bronx, New York 2 Department of Radiation Oncology, Montefiore Medical Center, Albert Einstein College of Medicine, Bronx, New York
\end{abstract}

Key words: Merkel cell carcinoma, radiotherapy, inoperable, relapse, survival

Citation: Patel P, Modi C, McLellan B, Ohri N. Radiotherapy for inoperable Merkel cell carcinoma: a systematic review and pooled analysis. Dermatol Pract Concept. 2018;8(2):149-157. DOI: https://doi.org/10.5826/dpc.0802a15

Received: November 12, 2017; Accepted: March 2, 2018; Published: April 30, 2018

Copyright: @2018 Patel et al. This is an open-access article distributed under the terms of the Creative Commons Attribution License, which permits unrestricted use, distribution, and reproduction in any medium, provided the original author and source are credited.

Funding: None.

Competing interests: The authors have no conflicts of interest to disclose.

All authors have contributed significantly to this publication.

Corresponding author: Nitin Ohri, MD, Department of Radiation Oncology, Montefiore Medical Center Albert Einstein College of Medicine, Bronx, NY 10467, USA. Tel. (718) 430-3682; Fax. (718) 430-8618. Email: ohri.nitin@gmail.com

\begin{abstract}
Background: Cumulative data on radiation monotherapy for Merkel cell carcinoma (MCC) is lacking.

Objective: We sought to synthesize all available data on treatment outcomes for radiation monotherapy for inoperable stage I-III MCC.

Methods: We performed a systematic review of the current literature. Articles published in English in the PubMed database up to July 29, 2016, were evaluated.

Results: Eight case reports, 4 case series, and 6 retrospective studies, yielding 68 patients, were included in our analysis. Of the 24 stage I/II patients treated with local irradiation, $6(25 \%)$ relapsed and $1(4 \%)$ died from MCC. Of the 24 stage I/II patients treated with local and regional nodal irradiation, $5(21 \%)$ relapsed and $2(8 \%)$ died from MCC. Of the 20 stage III patients treated with local and regional nodal irradiation, $12(60 \%)$ relapsed and $7(35 \%)$ died from MCC.

Conclusions: Radiation monotherapy appears to be a reasonable treatment modality for patients with inoperable stage I-III MCC. Further investigation with prospective studies is needed to draw definitive conclusions.
\end{abstract}

\section{Introduction}

Merkel cell carcinoma (MCC) is an aggressive tumor of the skin and mucous membranes first described by Toker in 1972 [1]. MCC classically presents as a rapidly growing, firm, violaceous nodule and is thought to be due to extensive radiation exposure and/or polyomavirus. Like melanoma, MCC has a strong propensity to recur locally, spread regionally, and disseminate widely, leading to a fatal outcome [1]. However, unlike melanoma, MCC is highly radiosensitive, with in vitro MCC cell lines demonstrating substantially lower surviving fractions (mean: 0.30) than melanoma cell lines (mean: 0.57) when exposed to 2 Gy of radiation [2].

Although there have been few prospective studies to guide management of the disease, it is generally agreed that for the primary tumor, surgery with or without adju- 
vant radiation therapy is the preferred treatment modality; for nodal involvement, node dissection and/or radiation therapy is the preferred treatment modality; and for distant metastasis, chemotherapy, radiation therapy and/or surgery should be considered [3]. When surgery is not possible due to tumor location and size, patient comorbidities, and/or patient refusal, radiation monotherapy is typically the preferred treatment modality, regardless of whether the intent is palliative or curative.

Due to the rarity of MCC, with an incidence of only 0.79 per 100,000 [4], the efficacy of radiotherapy for inoperable MCC is not well defined. Here we present a systematic review of the literature to evaluate radiation monotherapy for MCC patients, focusing on the effects of local and regional radiation therapy on relapse and survival. We hope the results of this article help raise awareness that radiation monotherapy, as opposed to other local-regional nonsurgical treatment modalities, is a reasonably effective option for patients with inoperable MCC.

\section{Methods and Materials}

\section{Data Search}

We searched the PubMed database for articles published in English up to July, 29 2016. The search terms included a combination of "Merkel cell carcinoma" or "merkel-cell carcinoma" and "radiation therapy" or "radiotherapy." The references of articles selected for full-text evaluation were also considered for additional studies.

\section{Inclusion/Exclusion Criteria}

All study types (case reports/series, retrospective studies and prospective studies) were considered in our analysis. Studies with the following criteria were included: 1) published in English, 2) published as a full article, 3) reported known primary MCCs without distant metastasis $\left(\mathrm{M}_{+}\right)$or prior treatment, 4) the primary treatment modality was radiation therapy without surgery and/or chemotherapy, and 5) reported tumor staging data, total radiation dose data, and at least one of the following primary outcomes data: recurrence, metastasis, or survival. For studies with aggregate data, if part of the patients in the aggregate data were treated with combination therapy (surgery and/or chemotherapy) the cohort was excluded because we could not determine what part of the data represented those patients who received radiation monotherapy.

\section{Study Selection, Quality Assessment and Data extraction}

Authors PP and CM independently searched the PubMed database and reviewed all the selected articles using the
Preferred Reporting Items for Systematic Reviews and MetaAnalyses (PRISMA) selection process (Figure 1). From the selected articles, the following data was extracted: language, author, date of publication, study design, sample size, age of patients at diagnosis, sex of patients, location and size of primary tumor, stage of cancer at diagnosis, total radiation dose, immunocompromised status, recurrence/metastasis, and survival. Discrepancies in opinion about article eligibility, the quality of studies, and/or data extraction, were reviewed jointly by PP and CM to achieve consensus.

\section{Quality Assessment}

The quality of the selected studies was evaluated according to the Grading of Recommendations Assessment, Development, and Evaluation (GRADE) guidelines (Table 1) [5]. The level of evidence supporting each article was determined using criteria from the Oxford Center for Evidence-based Medicine (Table 1) [6].

\section{Data Analysis}

Survivorship estimates were generated using descriptive statistics and the Kaplan-Meier method in Graphpad Prism 6 (Graphpad Software Inc., La Jolla, CA). For the analysis of relapse-free survival, the endpoint was any recurrence or metastasis; for the analysis of overall survival, the endpoint was death from any cause; and for the analysis of causespecific survival the endpoint was death from MCC.

Aggregate and individual patient data were combined using the two-stage method, with a fixed- or random-effects approach, in Comprehensive Meta Analysis 2.0 (Biostat Inc., Englewood, NJ) [7,8]. Based on Cochran's Q test for heterogeneity, the fixed-effects model was only used if the $\mathrm{P}$ value $>$ 0.1 [9]. When aggregate data was reported as a median, the mean and variance were estimated using distribution-free formulas [10].

Tumor staging was standardized using the 2010 TNM staging system for MCC [11]. A tumor was considered stage I if it was $<2 \mathrm{~cm}$ with no metastases; stage II if it was $2-5 \mathrm{~cm}$ with no metastases; stage III if there was lymph node metastasis; and stage IV if distant metastasis occurred. Local recurrence was defined as recurrence within or adjacent to the primary site; regional recurrence was defined as recurrence in the regional nodal basin or in-transit metastasis (cutaneous/ intradermal metastasis en-route to the regional nodal basin), and distant metastasis was defined as tumor spreading distant to the regional nodal basin.

\section{Results}

\section{Description of Studies}

An initial search of the PubMed database identified 586 records. A title-abstract screen resulted in 83 arti- 


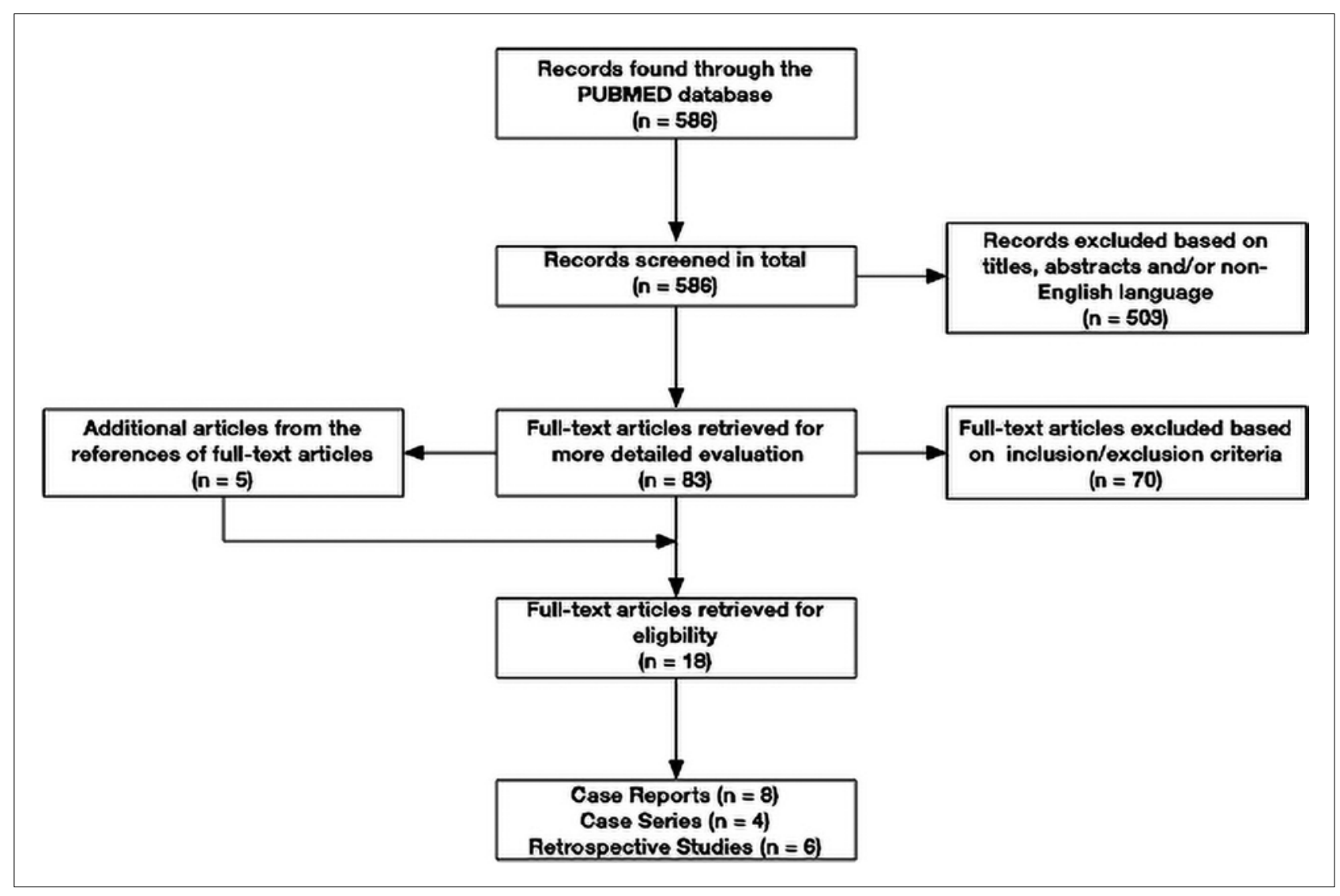

Figure 1. Preferred Reporting Items for Systematic Reviews and Meta-Analyses (PRISMA) selection process.

TABLE 1. Study characteristics and quality assessment

\begin{tabular}{|c|c|c|c|c|c|c|}
\hline Author(s) & $\begin{array}{c}\text { Year } \\
\text { Published }\end{array}$ & Study Design & $\begin{array}{c}\text { Comparative/ } \\
\text { Non-comparativet }\end{array}$ & $\begin{array}{l}\text { Sample Sizeł } \\
\qquad(n=68)\end{array}$ & $\begin{array}{l}\text { Level of } \\
\text { Evidence }\end{array}$ & $\begin{array}{l}\text { GRADE } \\
\text { Quality }\end{array}$ \\
\hline Ashby et al [40] & 1989 & Case series & Non-comparative & 1 & 4 & Very Low \\
\hline Chatzinasiou et al [41] & 2015 & Case report & Non-comparative & 1 & 4 & Very Low \\
\hline Elliot [42] & 1981 & Case report & Non-comparative & 1 & 4 & Very Low \\
\hline Handa et al [43] & 2000 & Case report & Non-comparative & 1 & 4 & Very Low \\
\hline Hasle et al [44] & 1991 & Case report & Non-comparative & 1 & 4 & Very Low \\
\hline Kitamura et al [45] & 2015 & Case report & Non-comparative & 1 & 4 & Very Low \\
\hline Lawenda et al [46] & 2008 & Retrospective & Non-comparative & 2 & 3 & Low \\
\hline Luaces Rey et al [47] & 2008 & Case series & Non-comparative & 1 & 4 & Very Low \\
\hline Magrini et al [48] & 1992 & Case series & Non-comparative & 1 & 4 & Very Low \\
\hline Makino et al [49] & 2005 & Case report & Non-comparative & 1 & 4 & Very Low \\
\hline Pacella et al [50] & 1988 & Retrospective & Non-comparative & 1 & 3 & Low \\
\hline Pape et al [12] & 2011 & Retrospective & Comparative & 25 & 3 & Low \\
\hline Seki et al [51] & 2003 & Case series & Non-comparative & 2 & 4 & Very Low \\
\hline $\begin{array}{l}\text { Suntharalingam et al } \\
{[52]}\end{array}$ & 1995 & Retrospective & Comparative & 2 & 3 & Low \\
\hline Tuskada et al [53] & 2016 & Case report & Non-comparative & 1 & 4 & Very Low \\
\hline Veness et al $[* 54,55]$ & $2009 / 2015$ & Retrospective & Non-comparative & 25 & 3 & Low \\
\hline Yamakawa et al [56] & 2008 & Case report & Non-comparative & 1 & 4 & Very Low \\
\hline
\end{tabular}

GRADE, Grading of Recommendations Assessment, Development and Evaluation

${ }^{*}$ Includes two articles that represent one cohort of patients

$\dagger$ Comparative refers to studies that had multiple treatment groups; non-comparative refers to studies that had only 1 treatment group

$\ddagger$ Only represents those relevant patients included in our study 
cles. After applying inclusion/exclusion criteria and removing duplicate data, 18 articles were included in our analysis. Of these articles, 8 were case reports, 4 were case series, and 6 were retrospective studies, yielding a total of 68 patients (Table 1 and Table 2).

\section{Stage I/II Disease}

Of the 68 patients treated with radiation monotherapy, 48 (71\%) presented with stage I/II MCC. Of these, 24 $(50 \%)$ underwent local tumor irradiation, and $24(50 \%)$ underwent local tumor and regional nodal irradiation. The mean duration of follow-up for patients in the local radiation group was 13.4 months (range: 3-42) and that for patients in the local-regional radiation group was 15.1 months (range: 4-35). The duration of follow-up was only available for 7 patients in the local radiation group and 9 patients in the local-regional radiation group. The mean total radiation dose to the primary tumor was 55.2 Gy (range: 20-70) in the local radiation group and $64.5 \mathrm{~Gy}$ (range: 38.5-70) in the local-regional radiation group. Patients in the localregional radiation group also received a mean total radiation dose of $50.8 \mathrm{~Gy}$ (range: 40-55) to the regional nodal basin (prophylactically).

The relapse rate in the local radiation group was $25 \%(\mathrm{n}=6 / 24)$ (1 local recurrence, 3 regional recurrences, and 2 distant metastasis) and that in the local-regional radiation group was $21 \%(\mathrm{n}=5 / 24)$ (1 local recurrence, 1 regional recurrence, 2 distant metastasis, and 1 unspecified recurrence/ metastasis). There were 5 reported deaths $(21 \%)$ in the local radiation group, of which 1 (4\%) was from MCC. There were 9 reported deaths (38\%) in the local-regional radiation group, of which $2(8 \%)$ were from MCC. If we assumed that all patients who were alive with disease at the last follow-up eventually died from MCC and all other patients did not die from MCC, the total number of deaths from MCC would

TABLE 2. Patient characteristics

\begin{tabular}{|c|c|c|c|}
\hline Patient Characteristics & $\begin{array}{l}\text { Stage I/II } \\
(n=48)\end{array}$ & $\begin{array}{l}\text { Stage III } \\
(n=20)\end{array}$ & $\begin{array}{l}\text { All Stages } \\
(n=68)\end{array}$ \\
\hline \multicolumn{4}{|l|}{ Sex } \\
\hline Male & $9(19 \%)$ & $13(65 \%)$ & $22(32 \%)$ \\
\hline Female & $37(77 \%)$ & $7(35 \%)$ & $44(65 \%)$ \\
\hline Unknown & $2(4 \%)$ & $0(0 \%)$ & $2(3 \%)$ \\
\hline \multicolumn{4}{|l|}{ Age at Diagnosis } \\
\hline$<60 y$ & $3(6 \%)$ & $2(10 \%)$ & $5(7 \%)$ \\
\hline $60-69 y$ & $7(15 \%)$ & $1(5 \%)$ & $8(12 \%)$ \\
\hline $70-79 y$ & $11(23 \%)$ & $7(35 \%)$ & $18(26 \%)$ \\
\hline$\geq 80 y$ & $25(52 \%)$ & $10(50 \%)$ & $35(52 \%)$ \\
\hline Unknown & $2(4 \%)$ & - & $2(3 \%)$ \\
\hline Mean Age y (range) & 77.8 (45-98) & $78.1(54-96)$ & $77.9(45-98)$ \\
\hline \multicolumn{4}{|l|}{ Location of Primary Tumor } \\
\hline Head and Neck & $35(73 \%)$ & $12(60 \%)$ & $47(69 \%)$ \\
\hline Trunk & - & $3(15 \%)$ & $3(4 \%)$ \\
\hline Upper Extremities & $2(4 \%)$ & $1(5 \%)$ & $3(4 \%)$ \\
\hline Lower Extremities & $10(21 \%)$ & $4(20 \%)$ & $14(21 \%)$ \\
\hline Unspecified Extremity & $1(2 \%)$ & - & $1(2 \%)$ \\
\hline \multicolumn{4}{|l|}{ Lesion Size } \\
\hline$\leq 2 \mathrm{~cm}$ & $21(44 \%)$ & $6(30 \%)$ & $27(40 \%)$ \\
\hline$>2 \mathrm{~cm}$ & $22(46 \%)$ & $13(65 \%)$ & $35(51 \%)$ \\
\hline Unknown & $5(10 \%)$ & $1(5 \%)$ & $6(9 \%)$ \\
\hline Mean Size cm (range) & $3.0(0.4-18)$ & $4.0(0.5-10)$ & $3.3(0.4-18)$ \\
\hline \multicolumn{4}{|l|}{ Immunosuppression } \\
\hline Yes & $2(4 \%)$ & $2(10 \%)$ & $4(6 \%)$ \\
\hline No & $46(96 \%)$ & $18(90 \%)$ & $64(94 \%)$ \\
\hline
\end{tabular}

increase to $5(21 \%)$ in the local radiation group and $5(21 \%)$ in the localregional radiation group (Table 3 ).

\section{Stage III Disease}

Of the 68 patients treated with radiation monotherapy, 20 (29\%) presented with stage III MCC. All of these patients were treated with local-regional radiation. The mean duration of follow-up for these patients was 18.9 months (range: 4-53). The mean total radiation dose to the primary tumor was $52.2 \mathrm{~Gy}$ (range: 20-70) and that to the regional nodal basin was 51.5 Gy (range: 20-70).

The relapse rate was $60 \%(n=12 / 20)$ (2 regional recurrences, 4 distant metastasis, and 6 unspecified recurrences/ metastases). There were 7 reported deaths $(35 \%)$ in the local-regional radiation group, all of which were from MCC. If we assumed that those patients who were alive with disease at the last follow-up eventually died from MCC and all other patients did not die from MCC, the number of deaths from MCC would increase to $10(50 \%)$ (Table 3$)$.

\section{Surgery plus Radiation vs. Radiation Monotherapy}

A retrospective study by Pape et al [12]. compared 25 stage I MCC patients treated with radiation monotherapy to 25 stage I MCC patients treated with surgery + radiation. In the radiation monotherapy group, the total dose of radiation was 70 Gy to the primary tumor for all patients and $\sim 50-55$ Gy 
TABLE 3. Treatment characteristics and outcomes

\begin{tabular}{|c|c|c|c|c|c|}
\hline Treatment & $\begin{array}{l}\text { Local } \\
\text { recurrence }\end{array}$ & $\begin{array}{l}\text { Regional } \\
\text { recurrence }\end{array}$ & $\begin{array}{l}\text { Distant } \\
\text { metastasis }\end{array}$ & $\begin{array}{l}\text { Unspecified } \\
\text { recurrence/ } \\
\text { metastasis }\end{array}$ & $\begin{array}{l}\text { Death from } \\
\text { MCC }\end{array}$ \\
\hline \multicolumn{6}{|l|}{ Stage I/II $(\mathrm{n}=48)$} \\
\hline \multicolumn{6}{|c|}{$\begin{array}{l}\text { Local Radiation monotherapy }(n=24) \\
\text { Mean duration of follow-up: } 13.4 \text { months (range: } 3-42)(n=7) *\end{array}$} \\
\hline Primary Tumor & \multicolumn{5}{|c|}{$\begin{array}{l}\text { Mean Total } \\
\text { Radiation Dose: } 55.2 \text { Gy (range: 20-70) }{ }^{\dagger} \\
\end{array}$} \\
\hline Event & $1(4 \%)$ & $3(13 \%)$ & $2(8 \%)$ & - & $1(4 \%)$ \\
\hline Time-to-event (months) & 3 & $6,7 *$ & 18,31 & - & 23 \\
\hline \multicolumn{6}{|c|}{$\begin{array}{l}\text { Local-regional radiation monotherapy }(n=24) \\
\text { Mean duration of follow-up: } 15.1 \text { months (range: } 4-35)(n=9) *\end{array}$} \\
\hline Primary Tumor & \multicolumn{5}{|c|}{$\begin{array}{l}\text { Mean Total } \\
\text { Radiation Dose: } 64.5 \text { Gy (range: } 38.5-70 \text { ) }\end{array}$} \\
\hline Nodal Basin & \multicolumn{5}{|c|}{$\begin{array}{l}\text { Mean Total } \\
\text { Radiation Dose: } 50.8 \text { Gy (range: 40-55) }\end{array}$} \\
\hline Event & $1(4 \%)$ & $1(4 \%)$ & $2(8 \%)$ & $1(4 \%)$ & $2(8 \%)$ \\
\hline Time-to-event (months) & 4 & 15 & 4,15 & 10 & 7,12 \\
\hline \multicolumn{6}{|c|}{ Stage $\mathrm{III}^{\ddagger}(\mathrm{n}=20)$} \\
\hline \multicolumn{6}{|c|}{$\begin{array}{l}\text { Local-regional radiation monotherapy }(n=20) \\
\text { Mean duration of follow-up: } 18.9 \text { months (range: } 4-53)(n=20)\end{array}$} \\
\hline Primary Tumor & \multicolumn{5}{|c|}{$\begin{array}{l}\text { Mean Total } \\
\text { Radiation Dose: } 52.2 \text { Gy (range: 20-70) }\end{array}$} \\
\hline Nodal Basin & \multicolumn{5}{|c|}{$\begin{array}{l}\text { Mean Total } \\
\text { Radiation Dose: } 51.5 \text { Gy (range: } 20-70 \text { ) }\end{array}$} \\
\hline Event & - & $2(10 \%)$ & $4(20 \%)$ & $6(30 \%)$ & $7(35 \%)$ \\
\hline Time-to-event (months) & - & 1 (in-transit), 2 & $1,3,6,9$ & $2,3,5,6,8,36$ & $\begin{array}{l}5,5,5,7,10 \\
10,14\end{array}$ \\
\hline
\end{tabular}

* Duration of follow-up (time from date of diagnosis to either outcome of interest or date of last follow-up) was not available for all patients

${ }^{\dagger}$ Fixed-effects model was used (heterogeneity $\mathrm{Q}=.221, \mathrm{I}^{2}<.001, \mathrm{P}=.638$ )

${ }^{*}$ All stage III patients were treated with local-regional radiation therapy

to the regional nodal basin for patients in the local-regional group. In the surgery + radiation group, the total dose of radiation was $\sim 50-55$ Gy to the surgical bed for all patients and 50-55 Gy to the regional nodal basin for patients in the local-regional group. There were 2 regional recurrences at 6 and 15 months in the radiation monotherapy group and 4 regional recurrences at 5, 16, 17 and 109 months in the surgery + radiation group. In this study, there was no significant difference in relapse-free survival (log-rank, $\mathrm{p}=.18$ ) or cause-specific survival (log-rank, $\mathrm{p}=.32$ ) between the radiation monotherapy group and surgery + radiation group [12].

\section{Discussion}

In this review, we have demonstrated that radiation monotherapy appears to be a reasonable treatment modal- ity for patients with inoperable stage I-III MCC. Compared to radiation monotherapy, isolated case reports of other nonsurgical treatment modalities using cryotherapy $[13,14]$, topical immunotherapy (dinitrochlorbenzol [15], imiquimod $[14,16,17])$, intralesional immunotherapy (interluekin-12 [18], tumor necrosis factor-alpha [19], interferon-alfa [16], interferon-beta [20], glucopyranosyl lipid-A [18]) and/or isolated limb perfusion with chemotherapy (melphalan, tumor necrosis factor-alpha +/interferon-gamma) [21,22], have shown variable efficacy, often with only transient response or adjuvant radiation therapy required for maintenance.

Despite the fact that patients treated with radiation monotherapy often have adverse prognostic features such as large lesion size and head and neck tumor location $[23,24]$, the incidences of relapse and death from MCC in the studied patients were similar, if not lower, than the 
incidences in similarly staged patients treated with surgery +/- radiation (Figure 2) [1,25-27]. We additionally found that in the absence of nodal disease (stage I/II) in patients with inoperable MCC, prophylactic radiation to the nodal basin resulted in a similar incidence of relapse and death as no prophylactic radiation to the nodal basin. Interestingly, in the only randomized trial evaluating prophylactic radiation to the nodal basin in MCC patients, nodal irradiation with a dose of 50 Gy was associated with a significant decrease in regional recurrences (log-rank, $\mathrm{p}=.007$ ) but no difference in overall survival (log-rank, $\mathrm{p}=.989$ ) or progression-free survival (log-rank, $\mathrm{p}=.400$ ) [28]. When considering nodal disease (stage III), however, radiation is typically provided to the nodal basin in patients with inoperable MCC, as was the case for all stage III patients included in this review. In fact, in a study where all the patients underwent surgery $+/$ - radiation to the primary tumor, it was suggested that radiation to nodal disease is comparable to nodal dissection +/- radiation, with no difference in 2-year regional recurrence-free survival (log-rank, $\mathrm{p}=1, \mathrm{p}=.8$ ) or disease-specific survival $(\log$-rank, $\mathrm{p}=.7, \mathrm{p}=.9)$ [29].

Currently, for inoperable stage I-III MCC, the 2016 NCCN (National Comprehensive Cancer Network) guidelines recommend a total radiation dose of 60-66 Gy to the primary tumor. Radiation monotherapy to the nodal basin is only recommended if there is clinical or microscopic nodal involvement, or if the patient is at risk for subclinical nodal disease. Unfortunately, the NCCN guidelines do not define who is at risk for subclinical nodal disease, leaving it to the treating physician's discretion. For clinical lymphadenopathy, 60-65 Gy is given; for microscopic nodal involvement, 50-56 Gy is given; and for patients at risk for subclinical nodal disease, 46-50 Gy is given. Typically, radiation of intransit lymphatics is not feasible unless the primary site is in close proximity to the nodal basin. In most settings, conventional radiotherapy fraction sizes of approximately 2 Gy/day are utilized (Figure 3). At this time, the NCCN guidelines do not recommend chemotherapy for inoperable stage I-III MCC. Chemotherapy is generally reserved for stage IV MCC (metastatic disease), although there is no high-level evidence demonstrating that chemotherapy prolongs overall survival in this setting [30]. While adding chemotherapy to radiation monotherapy has the theoretical advantage of radiosensitizing MCC, there is limited data justifying this approach for local or regional radiation, and it could possibly even worsen prognosis due to immunosuppression [26,31]. Systemic immunotherapy with recently developed checkpoint inhibitors is a promising approach for the treatment of advanced MCC [32]. Anecdotal data [33] and results from early phase trials [34] for other malignancies suggest that the combination of systemic immunotherapy and radiotherapy should be explored in MCC.
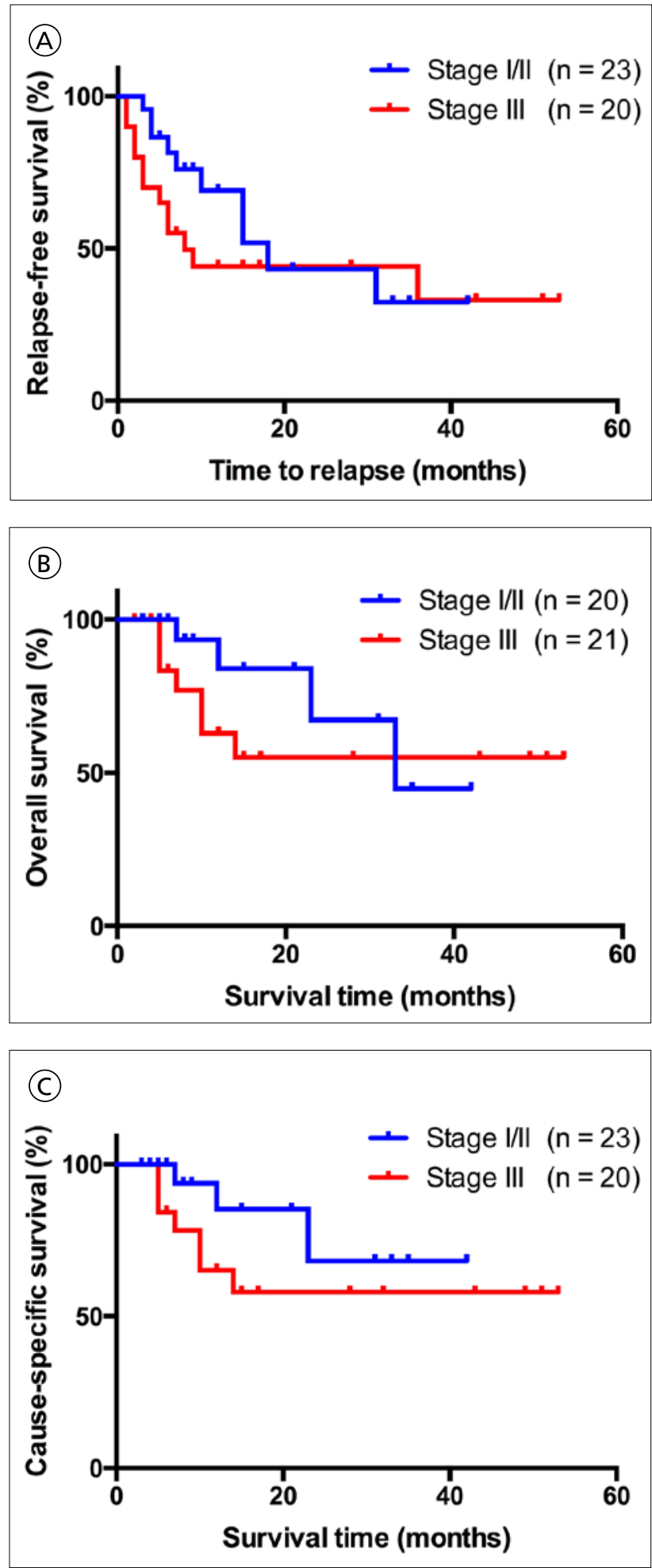

Figure 2. Kaplan-Meier survival curves. (a) Relapse-free survival curve; (b) Overall survival curve; (c) Cause-specific survival curve. [Copyright: @2018 Patel et al.]

While the response of MCC to radiation therapy is impressive, radiation therapy is not without toxicity; cumulative experience from the treatment of non-melanoma skin cancer indicates that nearly all patients treated with potentially curative radiotherapy doses will develop at least mild-tomoderate acute side effects such as atrophy, pigment change, 


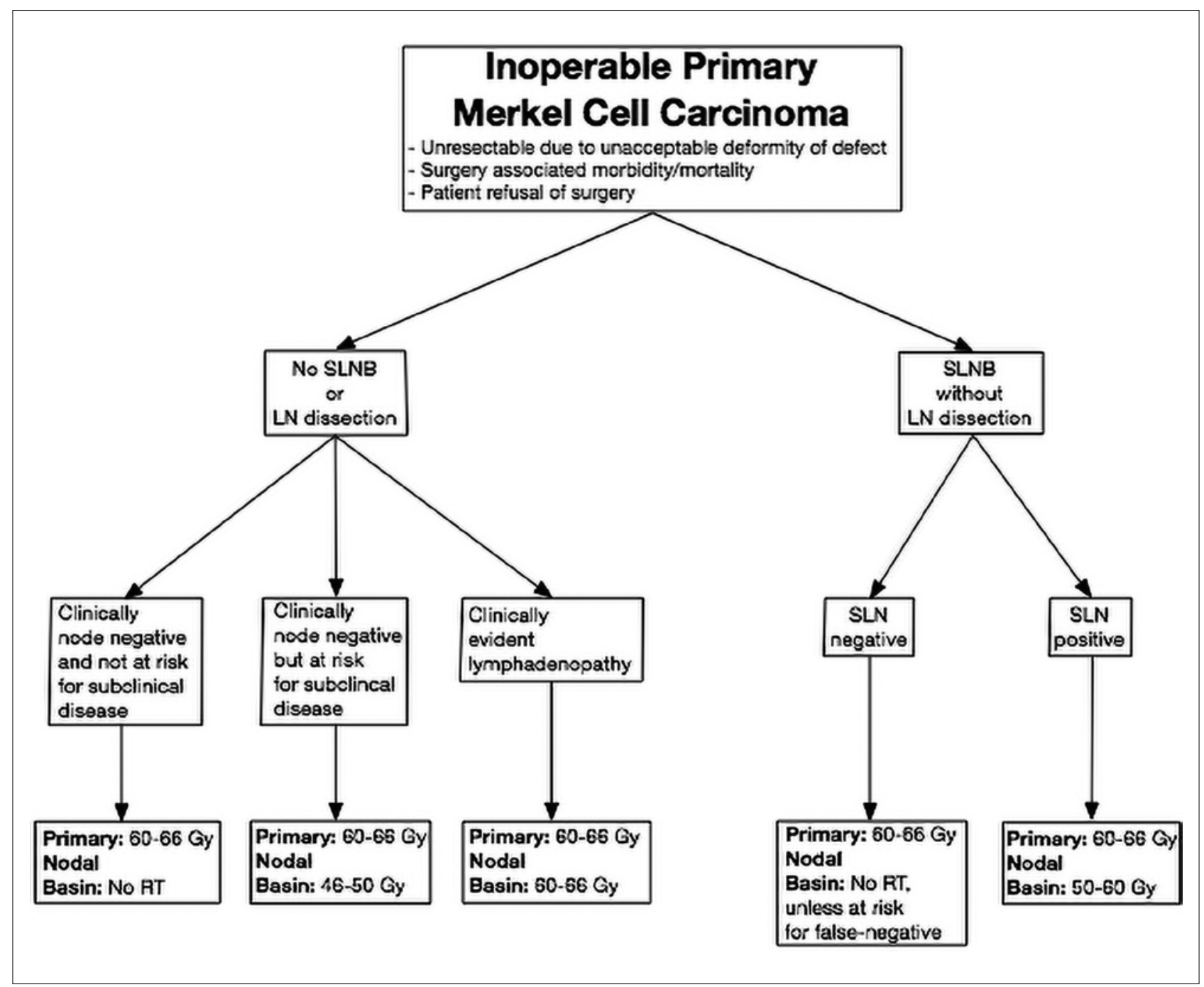

Figure 3. Radiation monotherapy recommendations for inoperable Stage I-III Merkel cell carcinoma. Modeled after the National Comprehensive Cancer Network's (NCCN) guidelines for Merkel Cell Carcinoma (Version 1.2016). Gy, Gray; LN, lymph node; SLN, sentinel lymph node; SLNB, sentinel lymph node biopsy. All doses are at 2 Gy/day standard fractionation. A less protracted fraction schedule may be used in the palliative setting such as $30 \mathrm{~Gy}$ in 10 fractions. Wide margins $(5 \mathrm{~cm})$ should be used, if possible, around the primary site. Radiation of in-transit lymphatics is often not feasible unless the primary site is in close proximity to the nodal basin. *NCCN Guidelines based on category 2A recommendations: Based upon lower-level evidence, there is uniform NCCN consensus that the intervention is appropriate. [Copyright: @2018 Patel et al.]

telangiectasia, or fibrosis [35,36]. Fortunately, serious or severe complications occur in only $\sim 1 \%$ of patients [37-39].

There are several limitations to our review. There was a dearth of available prospective studies, requiring us to rely on observational studies. This introduces a high risk of bias to our data and confounding factors that may obscure the overall results. Our search also yielded a small sample of patients treated with radiation monotherapy, and many studies lacked detailed information regarding follow-up time and radiation techniques used. This limited the power of the conclusions that could be drawn from our results. Pooled analysis of individual patient data from several large institutions and/or analysis of registry data should be pursued to further describe the use and efficacy of radiotherapy in the management of MCC.

\section{Conclusions}

To our knowledge, this is the first review to collectively present the outcomes of MCC patients treated with radiation monotherapy. Available data suggest that radiation monotherapy may be able to provide reasonable outcomes for MCC patients unable to undergo surgery. Prospective studies are sorely needed to guide the management of this rare and potentially fatal disease.

\section{References}

1. Lewis KG, Weinstock MA, Weaver AL, Otley CC. Adjuvant local irradiation for Merkel cell carcinoma. Arch Dermatol. 2006;142(6):693-700. 
2. Leonard JH, Ramsay JR, Kearsley JH, Birrell GW. Radiation sensitivity of Merkel cell carcinoma cell lines. Int J Radiat Oncol Biol Phys. 1995;32(5):1401-1407.

3. NCCN Guidelines 2016: Merkel Cell Carcinoma. Available from: https://merkelcell.org/wp-content/uploads/2015/10/MccNccn. pdf. Accessed November 1, 2016.

4. Fitzgerald TL, Dennis S, Kachare SD, Vohra NA, Wong JH, Zervos EE. Dramatic Increase in the Incidence and Mortality from Merkel Cell Carcinoma in the United States. Am Surg. 2015;81(8):802-806.

5. Balshem H, Helfand M, Schunemann HJ, Oxman AD, Kunz R, Brozek J, et al. GRADE guidelines: 3. Rating the quality of evidence. J Clin Epidemiol. 2011;64(4):401-406.

6. Oxford Centre for Evidence-Based Medicine 2011 Levels of Evidence. Available from: http://www.cebm.net/index.aspx?o=5653. Accessed September 1, 2016.

7. Riley RD, Simmonds MC, Look MP. Evidence synthesis combining individual patient data and aggregate data: a systematic review identified current practice and possible methods. J Clin Epidemiol. 2007;60(5):431-439.

8. DerSimonian R, Laird N. Meta-analysis in clinical trials. Control Clin Trials. 1986;7(3):177-188.

9. O'Dell CS, Grayson CJ, Essaides N. If Only We Knew What We Know: The Transfer Of Internal Knowledge And Best Practice. New York: Free Press; 1998:xvii, 238.

10. Hozo SP, Djulbegovic B, Hozo I. Estimating the mean and variance from the median, range, and the size of a sample. BMC Med Res Methodol. 2005;5:13.

11. Edge SB, American Joint Committee on Cancer. American Cancer Society. AJCC Cancer Staging Handbook: From The AJCC Cancer Staging Manual. 7th ed. New York: Springer; 2010:xix, 718.

12. Pape E, Rezvoy N, Penel N, Salleron J, Martinot V, Guerreschi P. Radiotherapy alone for Merkel cell carcinoma: a comparative and retrospective study of 25 patients. J Am Acad Dermatol. 2011;65(5):983-990.

13. Nagy J, Feher LZ, Sonkodi I, Lesznyak J, Ivanyi B, Puskas LG. A second field metachronous Merkel cell carcinoma of the lip and the palatine tonsil confirmed by microarray-based comparative genomic hybridisation. Virchows Arch. 2005;446(3):278-286.

14. Voulgari PV, Gaitanis G, Markatseli TE, Kempf W, Bassukas ID. In transit recurrence of Merkel cell carcinoma associated with polyarthritis effectively treated with immunocryosurgery. Acta Derm Venereol. 2014;94(6):739-740.

15. Herrmann G, Groth W, Krieg T, Mauch C. Complete remission of Merkel cell carcinoma of the scalp with local and regional metastases after topical treatment with dinitrochlorbenzol. J Am Acad Dermatol. 2004;50(6):965-969.

16. Wahl RU, Braunschweig T, Ghassemi A, Rubben A. Immunotherapy with imiquimod and interferon alfa for metastasized Merkel cell carcinoma. Curr Oncol. 2016;23(2):e150-153.

17. Scott DR. Apparent response of cutaneous Merkel cell tumor to topical imiquimod. Cutis. 2006;77(2):109-10; author reply 10.

18. Vandeven N, Nghiem P. Rationale for immune-based therapies in Merkel polyomavirus-positive and -negative Merkel cell carcinomas. Immunotherapy. 2016;8(8):907-921.

19. Hata Y, Matsuka K, Ito O, Matsuda H, Furuichi H, Konstantinos A. Two cases of Merkel cell carcinoma cured by intratumor injection of natural human tumor necrosis factor. Plast Reconstr Surg. 1997;99(2):547-553.
20. Nakajima H, Takaishi M, Yamamoto M, Kamijima R, Kodama H, Tarutani M.Screening of the specific polyoma virus as diagnostic and prognostic tools for Merkel cell carcinoma. J Dermatol Sci. 2009;56(3):211-213.

21. Ponte P, Moniz JV, Farricha V, Weinholtz JB. Merkel cell carcinoma: an unusual indication for isolated limb perfusion. Dermatol Online J. 2008;14(7):6.

22. Olieman AF, Lienard D, Eggermont AM, Kroon BB, Lejeune FJ, Hoekstra HJ. Hyperthermic isolated limb perfusion with tumor necrosis factor alpha, interferon gamma, and melphalan for locally advanced nonmelanoma skin tumors of the extremities: a multicenter study. Arch Surg. 1999;134(3):303-307.

23. Prieto Munoz I, Pardo Masferrer J, Olivera Vegas J, Medina Montalvo MS, Jover Diaz R, Perez Casas AM. Merkel cell carcinoma from 2008 to 2012: reaching a new level of understanding. Cancer Treat Rev. 2013;39(5):42142-9.

24. Becker JC. Merkel cell carcinoma. Ann Oncol. 2010;21 Suppl 7:vii81-85.

25. Medina-Franco H, Urist MM, Fiveash J, Heslin MJ, Bland KI, Beenken SW. Multimodality treatment of Merkel cell carcinoma: case series and literature review of 1024 cases. Ann Surg Oncol. 2001;8(3):204-208.

26. Allen PJ, Bowne WB, Jaques DP, Brennan MF, Busam K, Coit DG. Merkel cell carcinoma: prognosis and treatment of patients from a single institution. J Clin Oncol. 2005;23(10):2300-2309.

27. Frohm ML, Griffith KA, Harms KL, Hayman JA, Fullen DR, Nelson CC. Recurrence and survival in patients with merkel cell carcinoma undergoing surgery without adjuvant radiation therapy to the primary site. JAMA Dermatol.2016;152(9):100011007.

28. Jouary T, Leyral C, Dreno B, Doussau A, Sassolas B, Beylot-Barry $M$. Adjuvant prophylactic regional radiotherapy versus observation in stage I Merkel cell carcinoma: a multicentric prospective randomized study. Ann Oncol. 2012;23(4):1074-1080.

29. Fang LC, Lemos B, Douglas J, Iyer J, Nghiem P. Radiation monotherapy as regional treatment for lymph node-positive Merkel cell carcinoma. Cancer. 2010;116(7):1783-1790.

30. Cardoso JC, Teixeira V, Tchernev G, Wollina U. Merkel cell carcinoma: a review and update on aetiopathogenesis, diagnosis and treatment approaches. Wien Med Wochenschr. 2013;163(1516):359-367.

31. Garneski KM, Nghiem P. Merkel cell carcinoma adjuvant therapy: current data support radiation but not chemotherapy. J Am Acad Dermatol. 2007;57(1):166-169.

32. Nghiem PT, Bhatia S, Lipson EJ, Kudchadkar RR, Miller NJ, Annamalai L. PD-1 Blockade with Pembrolizumab in Advanced Merkel-Cell Carcinoma. N Engl J Med. 2016;374(26):2542-52.

33. Postow MA, Callahan MK, Barker CA, Yamada Y, Yuan J, Kitano S. Immunologic correlates of the abscopal effect in a patient with melanoma. N Engl J Med. 2012;366(10):925-31.

34. Seung SK, Curti BD, Crittenden M, Walker E, Coffey T, Siebert JC. Phase 1 study of stereotactic body radiotherapy and interleukin-2-tumor and immunological responses. Sci Transl Med. 2012;4(137):137ra74.

35. Lee J, Poon I, Balogh J, Tsao M, Barnes E. A review of radiotherapy for merkel cell carcinoma of the head and neck. J Skin Cancer. 2012;2012:563829.

36. Salvo N, Barnes E, van Draanen J, et al. Prophylaxis and management of acute radiation-induced skin reactions: a systematic review of the literature. Curr Oncol. 2010;17(4):94-112. 
37. Silva JJ, Tsang RW, Panzarella T, Levin W, Wells W. Results of radiotherapy for epithelial skin cancer of the pinna: the Princess Margaret Hospital experience, 1982-1993. Int J Radiat Oncol Biol Phys. 2000;47(2):451-459.

38. Hayter CR, Lee KH, Groome PA, Brundage MD. Necrosis following radiotherapy for carcinoma of the pinna. Int J Radiat Oncol Biol Phys. 1996;36(5):1033-1037.

39. Nguyen MT, Billington A, Habal MB. Osteoradionecrosis of the skull after radiation therapy for invasive carcinoma. J Craniofac Surg. 2011;22(5):1677-1681.

40. Ashby MA, Jones DH, Tasker AD, Blackshaw AJ. Primary cutaneous neuroendocrine (Merkel cell or trabecular carcinoma) tumour of the skin: a radioresponsive tumour. Clin Radiol. 1989;40(1):85-87.

41. Chatzinasiou F, Papadavid E, Korkolopoulou P, Levidou G, Panayiotides I, Theodoropoulos K. An unusual case of diffuse Merkel cell carcinoma successfully treated with low dose radiotherapy. Dermatol Ther. 2015;28(5):282-286.

42. Elliott E. Trabecular cell carcinoma-report of a case. Ann Plast Surg. 1981;7(2):163-164.

43. Handa Y, Yamanaka N. A case of Merkel cell carcinoma of the antebrachium successfully treated with only radiotherapy. Skin Cancer. 2000;15(2):163-169.

44. Hasle H. Merkel cell carcinoma: the role of primary treatment with radiotherapy. Clin Oncol (R Coll Radiol). 1991;3(2):114116.

45. Kitamura N, Tomita R, Yamamoto M, Yoshizawa Y, Sasabe E, Yamada T. Complete remission of Merkel cell carcinoma on the upper lip treated with radiation monotherapy and a literature review of Japanese cases. World J Surg Oncol. 2015;13:152.

46. Lawenda BD, Arnold MG, Tokarz VA, Silverstein JR, Busse PM, McIntyre JF. Analysis of radiation therapy for the control of Merkel cell carcinoma of the head and neck based on 36 cases and a literature review. Ear Nose Throat J. 2008;87(11):634-643.

47. Luaces Rey R, Fernandez Alba J, Martin R, Garcia Rozado A, Paradela S, Robles O. Merkel cell carcinoma of the head and neck: report of seven cases. Med Oral Patol Oral Cir Bucal. 2008;13(6):E390-394.

48. Magrini SM, Bianchi S, Mungai V, Biti G. Merkel cell carcinoma: report of two cases and clinical considerations. J Surg Oncol. 1992;49(2):131-1314.

49. Makino E, Sasae M, Sasaoka S, Inaoki M, Fujimoto W, Hiratsuka J. Radiation monotherapy for Merkel cell carcinoma: A case report and literature review of Japanese cases. Skin Cancer. 2005;20(3):329-33.

50. Pacella J, Ashby M, Ainslie J, Minty C. The role of radiotherapy in the management of primary cutaneous neuroendocrine tumors (Merkel cell or trabecular carcinoma): experience at the Peter MacCallum Cancer Institute (Melbourne, Australia). Int J Radiat Oncol Biol Phys. 1988;14(6):1077-1084.

51. Seki S, Shimada A, Arakura F, Iijima M, Uhara H, Kawachi S, et al. Two cases of Merkel cell carcinoma of the upper eyelid treated by radiotherapy. Skin Cancer. 2003;18(1):22-27.

52. Suntharalingam M, Rudoltz MS, Mendenhall WM, Parsons JT, Stringer SP, Million RR. Radiotherapy for Merkel cell carcinoma of the skin of the head and neck. Head Neck. 1995;17(2):96-101.

53. Tuskada A, Fujimura T, Hashimoto A, Kambayashi Y, Furudate S, Haga T. Successful local control of cutaneous Merkel cell carcinoma on the eyelid with CyberKnife radiosurgery. Eur J Dermatol. 2013;23(5):725-726.

54. Veness M, Howle J. Patients with clinically node negative extremity Merkel cell carcinoma: The importance of identifying and treating patients with microscopic nodal metastases. Australas J Dermatol. 2010;51(4):274-278.

55. Veness M, Howle J. Radiotherapy alone in patients with Merkel cell carcinoma: the Westmead Hospital experience of 41 patients. Australas J Dermatol. 2015;56(1):19-24.

56. Yamakawa M, Mizuno M, Tokumaru A, et al. An elderly patient with Merkel cell carcinoma treated by twice-a-week electron therapy. Jpn J Clin Radiol. 2008;53:1023-1027. https://www. researchgate.net/publication/288813032_An_elderly_patient_ with_Merkel_cell_carcinoma_treated_by_twice-a-week_electron_therapy. Accessed April 29, 2018. 